\title{
ОЗЕЛЕНЕНИЕ КРУПНЫХ ГОРОДОВ БАЙКАЛЬСКОГО РЕГИОНА - ИРКУТСКА, УЛАН-УДЭ, ЧИТЫ И УЛАН-БАТОРА
}

\author{
А. П. Суходолов ${ }^{1}$, Е. В. Потапова ${ }^{2}$, А. А. Изместьев ${ }^{1}$, И. К. Гусева ${ }^{1}$ \\ ${ }^{1}$ Байкальский государственный университет, г. Иркутск, Российская Федерация \\ 2 Иркутский государственный университет, г. Иркутск, Российская Федерация
}

\section{Информация о статье \\ Дата поступления \\ 27 марта 2018 г.}

Дата принятия к печати 21 мая 2018 г.

Дата онлайн-размещения 8 июня 2018 г.

\section{Ключевые слова}

Озеленение городов; насаждения; глобальные проблемы; анализ состояния территорий; регламент содержания насаждений

\begin{abstract}
Аннотация
Почти все крупные города имеют сходные проблемы, прежде всего экологические, связанные с озеленением. Города Байкальского региона не исключение. Для оценки состояния озеленения городов-столиц, расположенных в пределах Байкальской природной территории, - Иркутска, Улан-Удэ, Читы, Улан-Батора - представлены результаты обследования более тысячи объектов (выбранных случайным образом) их озеленения на предмет структуры, состояния и содержания с применением наземных полевых методов (описание, ведомости описания деревьев, фрейм-сценарии) и методов дистанционного зондирования Земли. За насаждения принимались лишь древесные (высотой более 2,5 м) и кустарниковые (более 1 м) растения. На момент обследования из 1118 объектов озеленения в девяти типах (парки, общественные здания, образовательные учреждения и учреждения здравоохранения, жилая застройка, водоохранные и санитарно-защитные зоны и др.) только 13 \% условно соответствовали регламенту их структуры и состояния. Еще около 20 \% отмечались как почти соответствующие, т. е. насаждения и структура озелененной территории имели 50 \% соответствия нормам. Около 40 \% обследованных объектов вообще не имели насаждений, на остальных 27 \% посадки отмечены единично.
\end{abstract}

\section{PLANTING OF GREENERY IN LARGE CITIES OF THE BAIKAL REGION: IRKUTSK, ULAN-UDE, CHITA AND ULAANBAATAR}

\author{
Alexander P. Sukhodolov' ${ }^{1}$, Elena V. Potapova ${ }^{2}$, Alexander A. Izmestiev ${ }^{1}$, Inessa K. Guseva ${ }^{1}$ \\ ${ }^{1}$ Baikal State University, Irkutsk, the Russian Federation \\ 2 Irkutsk State University, Irkutsk, the Russian Federation
}

Article info

Received

March 27, 2018

Accepted

May 21, 2018

Available online

June 8, 2018

\section{Keywords}

Settlements; plantings; global problems; analysis of a state; regulations of contents

\begin{abstract}
Almost all big cities have similar problems, first of all, environmental ones, concerning planting of greenery. The Baikal Region cities are not an exception. To estimate the state of greening of the capital cities Irkutsk, Ulan-Ude, Chita, Ulaanbaatar, situated within the Baikal natural area, the results of the inspection of more than one thousand objects (chosen randomly), of their greening with regard to the structure, state and maintenance with the use of land-based field technique (description, trees inspection records, frame scripts) and remote Earth sensing techniques. Solely woody plants (more than 2,5 $\mathrm{m}$ high) and brushwood (more than $1 \mathrm{~m}$ high) were taken for plantings. At the moment of inspection only $13 \%$ of 1118 planting objects in nine types (parks, public facilities, educational and public health facilities, residential construction, water and sanitary protection areas, etc.) conditionally conformed with the structure and state regulations.
\end{abstract}


About $20 \%$ were considered almost conforming, i. e. the plantings and the structure of the green area $50 \%$ conformed with regulations. About $40 \%$ of the inspected objects did not have any plantings at all and in the rest $27 \%$ single plantings were pointed out.

Введение. Все крупные города имеют сходные проблемы, прежде всего экологические, связанные с их озеленением. Крупные города Байкальского региона не исключение, несмотря на свое особое месторасположение (в пределах Байкальской природной территории) и влияние на природный объект Всемирного наследия - озеро Байкал.

Байкальская природная территория - условное понятие, но оно широко используется в научных и публицистических работах, а также в нормативно-правовых документах, например в фредеральной целевой программе «Охрана озера Байкал и социально-экономическое развитие Байкальской природной территории на 2012-2020 годы». Данная территория не имеет четко обозначенных границ, к ней обычно относят:

1) собственно озеро Байкал и его водоохранную зону шириной 1000 м;

2) его водосборную площадь;

3) особо охраняемые природные территории, прилегающие к озеру Байкал, а также территорию шириной до 200 км на запад и северо-запад от него, и это в пределах как Российской Федерации ${ }^{1}$, так и Монголии [1].

Байкальская природная территория находится почти в центре Азии, удалена от морей и характеризуется слабо развитой дорожно-транспортной сетью, огромными неосвоенными и слабо освоенными территориями, неравномерным размещением населения, отрицательными миграционными потоками, загрязнением окружающей среды вследствие наличия крупных энергопромышленных объектов и др. [2]. Ценность и значимость Байкальской природной территории обусловлены наличием уникального - самого большого пресноводного озера планеты. Однако проблемы, особенно качества среды, остаются практически не решенными.

Именно на этой значимой для России и мирового сообщества территории расположены крупные города - Иркутск, Улан-Удэ, Чита и Улан-Батор, имеющие общие особенности:

- постоянно высокие показатели загрязненности среды, когда, например, уровень загрязнения атмосферного воздуха превышает санитарные нормы и ПДК обычно по нескольким веществам и в несколько раз;

1 Охрана озера Байкал : сайт / Росгеолфонд. URL: http: / /geol.irk.ru/baikal.
- стабильное увеличение количества автотранспорта (обычно не нового);

- наличие крупных энергетических и промышленных объектов;

- увеличение водопотребления и отсутствие своевременного обновления систем канализационной очистки;

- рост объемов образующихся отходов и отсутствие полноценных полигонов ТБО [3];

- ежегодное уменьшение площади озелененных территорий, деградация или отсутствие пригородных зеленых зон.

По данным ВО3, на каждого горожанина в ближайшей перспективе должно приходиться $50 \mathrm{M}^{2}$ городских и $300 \mathrm{M}^{2}$ пригородных насаждений ${ }^{2}$. В городах РФ такая обеспеченность редко превышает 10-15 м². Этот показатель был достигнут в 2000-х гг., когда за счет перевода площадей пригородных зеленых зон в статус городских лесов при генеральном планировании произошел формальный рост с 3-8 м $^{2}$ - уровня, имевшего место в 1990-х гг. Так, в Иркутске площадь с 6,8 $\mathrm{M}^{2}$ на человека увеличилась до 13,2 м² в 2015 г. ${ }^{3}$ Вот только зеленые зоны, которые должны окружать поселения, ослабляя их влияние на окружающую природную среду, практически отсутствуют, заняты городами-спутниками, коттеджными поселками, сельскохозяйственными угодьями и др. В условиях современного градостроительства насаждения остаются неотъемлемой частью городской среды и рассматриваются как важный элемент застройки, благоустройства, устойчивого развития и обеспечения экологической безопасности.

В связи с общемировой уникальностью, колоссальной индивидуальностью, реликтовыми и эндемическими составляющими для оценки состояния территорий, входящих в условные границы Байкальской природной территории, представлен анализ структуры озелененных территорий самых крупных городов - столиц Иркутской области, Республики Бурятия, Забайкальского края и Монголии. Все рассматриваемые

2 Городские зеленые зоны: краткое руководство к действию. URL: http://green-shield.ru/wp-content/ uploads /2017/10/Rekomendatsii-VOZ-Urban-GreenSpaces_RUS_WHO_web.pdf.

3 Градостроительство. Генеральный план города. Документация по планировке территорий г. Иркутска : офиц. портал города Иркутска. URL: https://admirk. ru/Pages/nedvizhimostistroitelstvo.aspx. 
регионы перешагнули 50-процентный уровень урбанизации, и значительная часть их населения проживает в границах столиц (табл. 1) 4 .

Методы исследования. Озелененные территории крупных городов Байкальского региона изучались полевыми методами в летние периоды 2013 и 2016 гг. (Улан-Удэ, Чита), 2005 и 2014 гг. (Улан-Батор), с 1994 по 2017 г. (Иркутск). Объекты преимущественно выбраны случайным образом, за исключением тех, которые для всех городов являются «центральными», - магазины, парки, улицы, больницы и т. д. Всего изучено 1118 озелененных территорий (табл. 2). Подробно представим информацию лишь о части из них.

Применялись наземные полевые методы (описание, составление схем объектов озеленения, ведомости описания деревьев, фрейм-сценарии, системный анализ урбоэкосистем) и методы дистанционного зондирования Земли для корректировки полевых материалов [4]. Названия объектов озеленения и их адреса приводятся по данным «Яндекс.Карты» и GoogleEarth. За насаждения на озелененной территории принимались деревья (высотой более

${ }^{4}$ Регионы России. Основные социально-экономические показатели городов : стат. сб. / Росстат. М., 2016. 442 c. ; Mongolian National Statistical Office : program of official statistics development (2006-2010). URL: http: / / www.en.nso.mn/index.php.
2,5 м) и кустарники (не менее 1 м). При этом учитывалось, что при полевых исследованиях (некоторые из них нормируются законодательством РФ, например СП 42.13330.2016 «Градостроительство. Планировка и застройка городских и сельских поселений») обязательными для каждой озелененной территории показателями являются следующие:

1. Соотношение территорий, занятых зелеными насаждениями, элементами благоустройства, сооружениями и застройкой, а также высота последней (не выше двух этажей).

2. Расстояние от насаждений до зданий, сооружений, коммуникаций. Оно не должно быть меньше 1,5 м до оси кустарника и 5,0 м до оси дерева с соответствующими диаметрами кроны.

3. Сомкнутость древесных, кустарниковых растений (соотношение между открытым небом и кронами), измеряется в долях единицы от 0,1 до 1,0.

Для некоторых типов объектов имеются конкретные требования к составу насаждений. Исследовались и многие другие показатели, которые в этой статье не анализируются $[5 ; 6]$.

Методика полевого обследования имеет отличительные особенности в зависимости от типа озелененной территории. Например, санитарно-защитные зоны и санитарные

Общие сведения о территориях

Таблица 1 Байкальского региона

\begin{tabular}{|c|c|c|c|c|c|}
\hline \multirow{2}{*}{ Регион } & \multirow{2}{*}{ Площадь, км² } & \multirow{2}{*}{$\begin{array}{c}\text { Численность } \\
\text { населения }\end{array}$} & \multicolumn{2}{|c|}{ Население столиц } & \multirow{2}{*}{$\begin{array}{c}\text { Удельный вес } \\
\text { городского населения, \% }\end{array}$} \\
\hline & & & чел. & $\%$ & \\
\hline Иркутская область & 774846 & 2403643 & $623736^{11}$ & $24^{1)}$ & 79 \\
\hline Республика Бурятия & 351334 & 984870 & 431922 & 44 & 59 \\
\hline Забайкальский край & 431892 & 1072579 & 347088 & 32 & 69 \\
\hline Монголия & 1564116 & 3119935 & 1405000 & 45 & 65 \\
\hline
\end{tabular}

Общее количество обследованных объектов озеленения

\begin{tabular}{|c|c|c|c|c|}
\hline \multirow[b]{2}{*}{ Город } & \multicolumn{3}{|c|}{ Изучено озелененных территорий } & \multirow{2}{*}{ Итого } \\
\hline & Общего пользования & $\begin{array}{c}\text { Ограниченного } \\
\text { пользования }\end{array}$ & $\begin{array}{c}\text { Специального } \\
\text { назначения }\end{array}$ & \\
\hline Иркутск (И) ${ }^{1)}$ & 58 & 680 & 51 & 789 \\
\hline Чита (Ч)1) & 10 & 50 & 21 & 83 \\
\hline Улан-Удэ (УУ)'1) & 28 & 90 & 25 & 143 \\
\hline Улан-Батор (УБ) ${ }^{1)}$ & 12 & 70 & 21 & 103 \\
\hline Всего & 108 & 890 & 120 & 1118 \\
\hline
\end{tabular}

1) В таблицах принято сокращение названий городов. 
разрывы изучались в первую очередь методами дистанционного зондирования территории, затем полученная информация об участках с насаждениями исследовалась в полевых условиях. Стандартные аналитические приемы также корректировались, поскольку использование статистических методов обработки полевых данных и применение усредненных материалов могли привести к некорректным выводам. При этом объекты озеленения анализировались отдельно с выделением общих трендов структуры, состояния и векторов развития. Учитывались также и фундаментальные ограничения математических методов, обусловленные огромными вариациями показателей объектов и изменчивостью отдельных их признаков, связанных с изменением состояния насаждений, в том числе катастрофического характера [7].

Результаты. Каждый населенный пункт - это застроенная территория, включающая дома, дворовые проезды, административные, общественные здания, автомобильные, другие дороги, и незастроенные участки, представляющие собой озелененные территории разной степени ухоженности и зарастания травянистыми, кустарниковыми и древесными растениями. С другой стороны, почти каждый объект застройки имеет окружающую его территорию, и она должна быть в той или иной степени озеленена. Только такой подход к рассмотрению структурно-функциональных элементов поселений имеет социальное, экологическое, эстетическое и санитарно-гигиеническое значение и приведет к устойчивому их развитию согласно современным тенденциям и мировому опыту развития населенных пунктов. Одной из важнейших частей функционального зонирования и обеспечения экологической составляющей городской среды, в том числе в аспекте обеспечения экосистемных услуг, являются полноценные по составу озелененные территории $[8]^{5}$. В России их делят на три категории - общего, ограниченного пользования и специального назначения 6 . Внутренняя их классификация разработана плохо, противоречива и рассматривается в разных нормативных документах.

${ }^{5}$ Global Report on Urban Health: Equitable, healthier cities for sustainable development / WHO and UN Habitat. URL: http://who.int/kobe_centre/measuring/urbanglobalreport/ugr_full_report.pdf?ua=1.

${ }^{6}$ ГОСТ 28329-89. Озеленение городов. М. : Стандартинформ, 2006. 22 с.
Озелененные территории общего пользования. Их преимущественное назначение - массовая рекреация, в том числе проведение крупных, значимых общественных мероприятий, гуляний, митингов и др. Большинство праздничных дней жители городов проводят именно на этих объектах озеленения. Данные об их совокупной площади информируют об обеспеченности жителей населенного пункта насаждениями. Следует указать, что доля и сомкнутость самих насаждений на территориях общего пользования не учитываются. Поэтому по площади объектов жители могут быть обеспечены насаждениями, а реально это могут быть территории без насаждений, оголенная до минерального слоя почва. Роль крупных зеленых массивов в городах велика, они в большой степени способствуют очищению атмосферы, комплексно оздоравливают среду и являются звеном, соединяющим современного человека с природой, дающим возможность ее познания.

Озелененные территории общего пользования подразделяются на следующие типы: городские леса, парки, скверы, сады и рощи, бульвары, аллеи, насаждения при административных и общественных зданиях, насаждения при стадионах. Некоторые из них рассмотрим подробно. Так, обследован 41 объект озеленения, это преимущественно наиболее крупные, центральные парки, скверы, сады и рощи. В большинстве из них (83 \%) преобладают деревья лиственных пород, что свидетельствует об их искусственном происхождении, и в связи с этим они утрачивают часть значимых функций в зимний период. Сомкнутость крон, за исключением насаждений на многих иркутских объектах, - меньше 0,5, т. е. редкое, разреженное стояние деревьев и показатель отсутствия их своевременного возобновления (табл. 3). Площади, занятые застройкой на этих объектах, не велики меньше $20 \%$ на 30 объектах, но имеет место незаконное строительство торговых центров, домов, гаражей по периметру 12 объектов. Габариты допустимой застройки - не выше двух этажей - соблюдаются на более чем 50 \% объектов. На всех объектах отмечена стихийная прокладка тропинок и даже дорог по причине неконтролируемой рекреации. Основной проблемой можно считать изреживание и повреждение насаждений при отсутствии превентивного возобновления. 
Характеристика некоторых парков, скверов, садов

Таблица 3

\begin{tabular}{|c|c|c|c|c|c|}
\hline $\begin{array}{c}\text { Объект } \\
\text { озеленения }\end{array}$ & $\begin{array}{c}\text { Сомкнутость, } \\
\text { долей / территория } \\
\text { под сооружениями, \% }\end{array}$ & $\begin{array}{l}\text { Породный } \\
\text { состав }\end{array}$ & $\begin{array}{l}\text { Социально зна- } \\
\text { чимые объекты }\end{array}$ & $\begin{array}{c}\text { Габариты } \\
\text { застройки"), } \\
\text { + или - }\end{array}$ & Примечания \\
\hline $\begin{array}{l}\text { Центральный парк } \\
(\text { (И) }\end{array}$ & $0,7 / 5,0$ & Смешанный & Зоопарк & + & $\begin{array}{c}\text { Разрежение } \\
\text { участками }\end{array}$ \\
\hline Роща Звездочка (И) & $0,9 / 1,0$ & Хвойный & Спортплощадки & + & $\begin{array}{c}\text { Почти модельный } \\
\text { объект }\end{array}$ \\
\hline $\begin{array}{l}\text { Парк Комсомоль- } \\
\text { ский (И) }\end{array}$ & $0,7 / 10,0$ & Лиственный & $\begin{array}{c}\text { Аттракционы, } \\
\text { памятник }\end{array}$ & + & Старые деревья \\
\hline ЦПКиО, горсад (УУ) & $0,0 / 20,0$ & Лиственный & $\begin{array}{c}\text { Церковь, торго- } \\
\text { вый центр }\end{array}$ & - & $\begin{array}{c}\text { Насаждения чуть } \\
\text { выше } 2 \text { м }\end{array}$ \\
\hline Юбилейный (УУ) & $0,5 / 20,0$ & Хвойный & Аттракционы & - & Застройка \\
\hline Сквер Победы (УУ) & $0,6 / 5,0$ & Лиственный & $\begin{array}{c}\text { Мемориал } \\
\text { победы }\end{array}$ & + & $\begin{array}{c}\text { Частичная } \\
\text { запущенность }\end{array}$ \\
\hline Центральный парк (Ч) & $0,0 / 15,0$ & Лиственный & $\begin{array}{c}\text { Мемориал по- } \\
\text { беды, часовня, } \\
\text { аттракционы }\end{array}$ & + & $\begin{array}{c}\text { Единичное стояние } \\
\text { деревьев }\end{array}$ \\
\hline Парк Пионеров (4) & $0,4 / 20,0$ & Хвойный & $\begin{array}{l}\text { Бассейн, } \\
\text { зоопарк }\end{array}$ & - & $\begin{array}{c}\text { Вместо } \\
\text { футбольного поля - } \\
\text { дом (2012) }\end{array}$ \\
\hline Парк Одора (Ч) & $0,2 / 40,0$ & Смешанный & $\begin{array}{l}\text { Аттракционы, } \\
\text { музей, техника }\end{array}$ & - & $\begin{array}{c}\text { В } 2004 \text { г. была } \\
\text { сомкнутость 0,6, } \\
\text { в } 2005 \text { г. - } \\
\text { реконструкция }\end{array}$ \\
\hline Парк Найрамдал (УБ) & $0,0 / 30,0$ & Лиственный & Аттракционы & + & $\begin{array}{c}\text { Насаждения чуть } \\
\text { выше } 2 \text { м }\end{array}$ \\
\hline $\begin{array}{l}\text { Парк на площади } \\
\text { Сукбаатар (УБ) }\end{array}$ & $0,0 / 15,0$ & Смешанный & $\begin{array}{l}\text { Памятники, } \\
\text { дорожки }\end{array}$ & + & $\begin{array}{c}\text { Дорожек больше, } \\
\text { чем деревьев }\end{array}$ \\
\hline $\begin{array}{l}\text { Эрдэнэсийн арал } \\
\text { цэцэрлэгт хүрээлэн } \\
\text { парк (УБ) }\end{array}$ & $0,4 / 45,0$ & Лиственный & Аттракционы & - & Детская площадка \\
\hline
\end{tabular}

Объекты озеленения этого типа четко делятся на две группы - ухоженные, используемые, популярные и запущенные, внутриквартальные. Рекреационная нагрузка в зависимости от объекта сильно разнится. Иркутск - единственный областной центр страны, где отсутствует центральный парк развлечений. В УланУдэ реконструкция затянулась на годы, а насаждений не прибавилось. В Улан-Баторе нет городских лесов и фрактически нет ни одного объекта озеленения, где сомкнутость насаждений больше 0,5, на большинстве объектов наблюдается единичное стояние деревьев. Похожая ситуация в Улан-Удэ. В последние десятилетия крупных объектов озеленения с насаждениями не создавалось ни в одном из анализируемых городов. Их появление на карте связано с присвоением какому-нибудь безымянному участку, даже в $50 \mathrm{~m}^{2}$, с растущими на нем лет 30 деревьями и кустарниками статуса и имени, например сквер им. Хаим-Бера Ходоса на ул. Ленина (Иркутск).

Озелененные территории при общественных и административных зданиях: музеях, театрах, торговых центрах, рынках, судах, библиотеках, объектах обслуживания населения, не относящихся к другим категориям, - это очень разнообразная группа с разбросом показателей от полной обеспеченности до полного отсутствия не просто насаждений, а места под их размещение. Было обследовано 67 объектов. Они характеризуются большей долей застройки и замощения и меньшей - озеленения. Около половины объектов вообще не имеют насаждений, около 20 \% имеют газоны или клумбы. У 12 \% объектов места для размещения насаждений нет (табл. 4). 
Таблица 4

Характеристика озеленения некоторых общественных и административных объектов

\begin{tabular}{|c|c|c|c|c|}
\hline Объект озеленения & $\begin{array}{l}\text { Наличие места } \\
\text { под насаждения } \\
\text { нас / в / ю / } 3\end{array}$ & $\begin{array}{c}\text { Наличие ДКР на } \\
\text { с / в / ю / 3, } \\
\text { шт. }\end{array}$ & $\begin{array}{c}\text { Нарушения } \\
\text { в размещении } \\
(5 \mathrm{M})\end{array}$ & Примечания \\
\hline Центральный рынок (И) & $+/-/+/+$ & $-/-/ 10 /-$ & + & Стоянки с трех сторон \\
\hline Драматический театр (И) & $+1+1-1+$ & $+{ }^{11} /+/+/-$ & + & Скверы с двух сторон \\
\hline $\begin{array}{l}\text { Железнодорожный } \\
\text { вокзал (И) }\end{array}$ & $+1+1+1+$ & 0 & - & Стоянка \\
\hline $\begin{array}{l}\text { Областная } \\
\text { администрация (И) }\end{array}$ & $+1+1+1+$ & $12 / 8 / 35 / 20$ & + & Очень банально и скудно \\
\hline Центральный рынок (УУ) & $-1+1+1-$ & 0 & *2) & Эстакада, стоянки \\
\hline Драмтеатр (УУ) & $+/+/+/+$ & $-/-/-/ 4$ & - & $\begin{array}{l}\text { Газоны, мощение } \\
\text { и вытаптывание }\end{array}$ \\
\hline $\begin{array}{l}\text { Железнодорожный } \\
\text { вокзал (УУ) }\end{array}$ & $+1+1-1+$ & 0 & - & $\begin{array}{c}\text { Два почти пустых больших } \\
\text { участка по бокам }\end{array}$ \\
\hline $\begin{array}{l}\text { Администрация Бурятии } \\
\text { (УУ) }\end{array}$ & $+1-1+1+$ & $-/-/ 10 /+$ & - & $\begin{array}{c}\text { На западе сквер, } \\
\text { ели }+5 \text { штук около } 2 \text { м }\end{array}$ \\
\hline Центральный рынок (Ч) & $+/+/+/+$ & $-/-/+/-$ & + & Единичные насаждения \\
\hline Драматический театр (Ч) & $+/+/+/+$ & $+/-/+/-$ & + почти все & $\begin{array}{c}\text { Единичные насаждения, } \\
\text { а места много }\end{array}$ \\
\hline $\begin{array}{l}\text { Железнодорожный } \\
\text { вокзал (Ч) }\end{array}$ & $+/+/+/+$ & 0 & * & Асфральт \\
\hline Администрация (Ч) & $+1+1+1+$ & $-1-1+1-$ & + & Ели в две полосы, стоянки \\
\hline Рынок Наран Туул (УБ) & $+1+1+1+$ & 0 & * & Стоянка \\
\hline $\begin{array}{l}\text { Рынок у } \\
\text { железнодорожного } \\
\text { вокзала (УБ) }\end{array}$ & $+1+1+1+$ & 0 & * & Стоянки \\
\hline $\begin{array}{l}\text { Национальный } \\
\text { драматический театр (УБ) }\end{array}$ & $+1-1+1+$ & $3(1) /(2) /-/-$ & & Сквер перед театром \\
\hline $\begin{array}{l}\text { Железнодорожный } \\
\text { вокзал (УБ) }\end{array}$ & $+/+/+/+$ & $5 /-/-/-$ & + & $\begin{array}{c}2(5-\text { меньше } 2 \text { м) } \\
\text { ели и кустарники }\end{array}$ \\
\hline Дворец правительства & $+/+/+1+$ & $* /-/-/-$ & * & Сквер при дворце \\
\hline
\end{tabular}

\begin{tabular}{|c|c|c|c|}
\hline Монголии (УБ) & $+1+1+1+$ & $x-1-1-$ & правительства ${ }^{3)}$ \\
\hline
\end{tabular}

1) + - насаждений много или имеется отдельный объект озеленения, реже - отсутствуют полные данные.

2) * - показатель выполняется, но ввиду отсутствия насаждений.

3) Закрыт для общественного посещения.

Озелененные территории общего пользования имеют первостепенное значение для формирования облика населенного пункта и обеспечения качества окружающей среды городов. Но сложилась ситуация, в которой насаждения этой категории пока существуют за счет накопленного резерва. Однако их возраст на большинстве объектов приближается к сенильному ввиду преждевременного старения в населенных пунктах, а отсутствие возобновления и интенсивного ухода может привести к одновременному коллапсу насаждений.

Озелененные территории ограниченного пользования. Категория озелененных территорий ограниченного пользования не имеет четкого определения и классификации даже в российском законодательстве, кроме разрозненного по нескольким градостроительным документам перечисления. Назначение таких территорий - также рекреация, но для групп, имеющих на них доступ, или для определенной категории граждан - учащихся, верующих, больных и др. Можно выявить следующие типы озелененных территорий озелененные территории при образовательных учреждениях, учреждениях здравоохранения, в пределах жилой застройки разного типа, при культовых объектах, храмах.

Озеленение территории учреждений здравоохранения определяется общей схемой планировки и целевым назначением насаждений. Для размещения корпусов и подсобных сооружений больницы обычно отводится территория значительных размеров с учетом возможности создания комплекса 
насаждений. Главными функциями насаждений этого типа, помимо архитектурного оформления территории, являются создание благоприятных санитарно-гигиенических условий для процедур и прогулок больных; улучшение режима инсоляции внутренних помещений в лечебных корпусах и защита этих помещений от ветра и пыли; разграничение территории на различные по функциональному назначению участки; изоляция проездов от основной площади.Было обследовано 100 объектов (табл. 5). Чаще всего это трех-пятиэтажные здания с небольшой территорией, иногда сходные с жилыми; лишь центральные больницы состоят из комплекса корпусов с большими участками. Значимыми показателями оценки состояния в этом типе озеленения считаются: наличие полосы озеленения по периметру (полностью не отмечено ни на одном объекте, на 21 \% объектов она значительно меньше половины, а на $28 \%$ вообще отсутствует); общая доля озеленения участка не менее 40 \% (соответствует на 17 объектах из обследованных, на 48 объектах - менее $20 \%$, на остальных полностью отсутствует). Хвойные деревья необходимы для выделения фитонцидов антибактериальных веществ, способствующих оздоровлению среды этих объектов, и обеспечения функции насаждений в зимний период. Но несмотря на это 74 \% обследованных объектов таких деревьев не имеют. Достаточная инсоляция помещений обеспечивается правильным расположением деревьев у здания - не ближе 5-10 м при соответствующем диаметре кроны, и даже этот показатель выполняется редко. А вот значительное вытаптывание территории до минерального почвенного горизонта отмечено на 57 \% объектов, на 28 \% - территории полностью заасфальтированы.

Таблица 5

Характеристика некоторых озелененных территорий учреждений здравоохранения

\begin{tabular}{|c|c|c|c|c|}
\hline Объект озеленения & $\begin{array}{c}\text { Место под насажде- } \\
\text { ния, да, нет / доля } \\
\text { ДКР (40\%) }\end{array}$ & $\begin{array}{c}\text { Нарушения } \\
\text { в размещении } \\
\text { насаждений } \\
(10 \mathrm{M})\end{array}$ & $\begin{array}{c}\text { Озеленение } \\
\text { по периме- } \\
\text { тру, \% }\end{array}$ & $\begin{array}{l}\text { Хвойные } \\
\text { деревья }\end{array}$ \\
\hline $\begin{array}{l}\text { Городская клиническая больница № } 1 \\
\text { (И) }\end{array}$ & Да / 10 & + & 5 & Единично \\
\hline Областная больница (И) & Да / 10 & *1) & - & - \\
\hline Детская городская больница (И) & Да / 5 & - & 20 & - \\
\hline Онкологический центр (И) & Да / 5 & * & 5 & - \\
\hline $\begin{array}{l}\text { Больница скорой помощи им. Агапова } \\
\text { (УУ) }\end{array}$ & Да / 20 & + & 30 & - \\
\hline $\begin{array}{l}\text { Республиканская клиническая больни- } \\
\text { ца им. Семашко (УУ) }\end{array}$ & Да / 5 & * & - & - \\
\hline Травмпункт № 1 (УУ) & Да / 0 & * & - & - \\
\hline $\begin{array}{l}\text { Детская республиканская клиническая } \\
\text { больница (УУ) }\end{array}$ & Да / 15 & + & 5 & - \\
\hline $\begin{array}{l}\text { Краевая детская клиническая больница } \\
\text { (Ч) }\end{array}$ & Да / 40 & + & 40 & Единично \\
\hline Госпиталь Минобороны (Ч) & Да / 15 & + & 35 & - \\
\hline Дорожная поликлиника № 1 (Ч) & $\begin{array}{c}\text { Да / } 0 \\
\text { (после } 2013 \text { г.) }\end{array}$ & - & 15 & Единично \\
\hline Центральная районная больница (Ч) & Да / 40 & - & 50 & Единично \\
\hline Больница Intermed (УБ) & Да / 0 & * & - & - \\
\hline $\begin{array}{l}\text { (Российский) Госпиталь по пр. Мира } \\
\text { (УБ) }\end{array}$ & Да / 20 & - & - & - \\
\hline Больница Shastin Central (УБ) & Да / 20 & + & - & - \\
\hline Больница Songdo (УБ) & Нет / 0 & * & - & - \\
\hline
\end{tabular}

\footnotetext{
1) * - показатель выполняется, но ввиду отсутствия насаждений.
} 
Озелененные территории при образовательных учреждениях, помимо выполнения образовательной функции (ознакомление детей с миром живой природы) и экологического воспитания, необходимы также для создания благоприятных микроклиматических и санитарно-гигиенических условий, особенно в детских садах, где учащиеся проводят много времени на территории. Для выполнения своего назначения к насаждениям применяются следующие требования:

1. По границам территории необходимы ограждение и защитная зеленая полоса из деревьев и кустарников шириной 5 м с расширением в местах примыкания детских площадок к границам участка до 10 м. Ограждения имеют все детские сады и 85 \% школ и средних учебных заведений, высшие учебные заведения практически не огорожены. Полноценной защитной полосы не отмечено ни на одном объекте (табл. 6).

2. Участок территории должен быть озеленен не менее чем на $40 \%$. В детских садах этот показатель выполняется на $49 \%$ объектов, и только вновь построенные (около 20 лет) почти не имеют насаждений. В школах ситуация хуже: показатель выполняется на $10 \%$ обследованных объектов, $30 \%$ совсем не озеленены или имеют единичные насаждения. Территории средних и высших образовательных учреждений озеленены не более $20 \%$ и только на $26 \%$ объектов.

3. Насаждения не должны препятствовать доступу солнечного света в здание; расстояние от окон до насаждений должно быть не менее 10 м, а до кустарников - не менее 5 м. Требование выполняется на 84 \% объектов, но на $38 \%$ - ввиду отсутствия насаждений.

Объем и ассортимент растений на участках при детских учреждениях, школах могут значительно варьироваться с учетом климата, размеров и плотности застройки населенных мест. Имеется важная рекомендация не использовать на этом типе озелененных территорий растения с колючками, ядовитыми плодами и производящие много мусора, обычно это плоды, семена. Так как этот критерий не всегда возможно изучить, то отметим лишь, что на 39 \% объектов из 50 \% обследованных по этому показателю были отмечены растения с колючками - шиповник, боярышник, карагана и др.

Можно с уверенностью утверждать, что за время исследования озеленение большого числа объектов (более $35 \%$ ) только ухудшилось, и не столько за счет естественной гибели,

Таблица 6

Характеристика некоторых озелененных территорий образовательных учреждений

\begin{tabular}{|c|c|c|c|c|}
\hline Объект озеленения & $\begin{array}{c}\text { Место под } \\
\text { насаждения, } \\
+,-/ \text { доля ДКР } \\
(40 \%)\end{array}$ & $\begin{array}{c}\text { Нарушения в разме- } \\
\text { щении насаждений } \\
(5 \mathrm{M})\end{array}$ & $\begin{array}{c}\text { Озеленение } \\
\text { по периметру, } \\
\text { \% }\end{array}$ & Примечание \\
\hline Школа № 2 (И) & $+/ 20$ & + & 40 & $\begin{array}{c}\text { Были тополя, } \\
\text { построили дома }\end{array}$ \\
\hline $\begin{array}{l}\text { Байкальский госуниверситет } \\
\text { (И) }\end{array}$ & $-1-$ & *1) & - & Во дворе посадки \\
\hline Детский сад № 103 (И) & $\begin{array}{c}+/ 20 \\
(10 \text { c } 2017 \text { г. })\end{array}$ & + & 10 & $\begin{array}{l}\text { Реконструкция } \\
\text { в } 2017 \text { г. }\end{array}$ \\
\hline $\begin{array}{l}\text { Национальный университет } \\
\text { Монголии (УБ) }\end{array}$ & $+/ 0$ & - & 0 & Сквер во дворе \\
\hline Школа № 3 (УБ) & $+/ 5$ & - & - & $\begin{array}{l}20 \text { обрезанных } \\
\text { в пень тополей }\end{array}$ \\
\hline $\begin{array}{l}\text { Детский сад в Кхору № } 18 \\
\text { (УБ) }\end{array}$ & $+/ 5$ & - & - & $\begin{array}{l}\text { По периметру } \\
\text { гаражи }\end{array}$ \\
\hline Школа № 3 (Ч) & $+/ 40$ & + & 10 & \\
\hline $\begin{array}{l}\text { Забайкальский госуниверси- } \\
\text { тет на ул. Баргузинской (Ч) }\end{array}$ & $+/ 5$ & * & 0 & Зарастание \\
\hline Детский сад № 32 (Ч) & $+/ 0$ & * & 0 & $\begin{array}{c}\text { До } 2014 \text { г. } \\
\text { был пустырь }\end{array}$ \\
\hline Гимназия № 33 (УУ) & $+/ 15$ & + & 20 & Гаражи \\
\hline $\begin{array}{l}\text { Бурятский госуниверситет } \\
\text { (УУ) }\end{array}$ & $+/ 15$ & + & 15 & \\
\hline Детский сад № 52 (УУ) & $+/ 10$ & + & 20 & \\
\hline
\end{tabular}


сколько по причине массовых капитальных ремонтов и реконструкций, прошедших за последние десять лет в нашей стране. В Улан-Баторе же оно практически не изменилось. Отметим и положительную тенденцию: в школах России выпускники стали сажать деревья.

Всего в этом типе обследовано 220 объектов. Озеленение территории у $41 \%$ объектов меньше $10 \%$ и отсутствует полностью, особенно у высших учебных заведений.

Придомовая территория - оформленный в установленном законодательством порядке земельный участок, на котором расположен (многоквартирный) жилой дом с элементами озеленения и благоустройства, включая территории, предназначенные для организации различных площадок отдыха, стоянок для автомашин, насаждений, пешеходных дорожек, проездов. Насаждения у этих объектов по разнообразию вносят самый большой вклад в общую картину структуры озеленения поселений. В последние десятилетия их доля уменьшается, состояние ухудшается, плановых посадок фактически не проводится. Новостройки во всех городах не обеспечиваются необходимым и даже запланированным озеленением, обычно отсутствуют места для размещения полноценных древесных насаждений. Такие проекты застройки вообще не должны быть реализованы, но действительность совершенно иная: города уплотняются в результате и точечной застройки, и возведения высотных жилых районов, совершенно не обеспеченных озеленением, а старая застройка теряет насаждения за счет естественного отпада, отведения участков под стоянки и устройства несанкционированных стоянок.

Проблемы придомовых насаждений связаны и с прямым их затенением домами, ограниченным увлажнением из-за асфальтового покрытия и своеобразия почвенных фракторов, из-за переуплотнения и недостатка элементов питания, а также с комплексной переэксплуатацией этих территорий. Постоянное стабильное уменьшение площадей озеленения и повреждение насаждений придомовых территорий наиболее характерны для центра городов, этим же местам свойственна наибольшая концентрация транспорта. Именно озеленение жилой застройки, в том числе крыш, стен и фасадов, должно обеспечить создание новых зеленых экогородов [9] $]^{7}$ Обследовано 570 объектов (табл. 7).

${ }^{7}$ Green Building Economic Impact Study / U.S. Green Building Council. Washington, 2013. 52p.
Таблица 7

Обобщенная оценка состояния придомовых территорий

\begin{tabular}{|c|c|c|c|c|}
\hline Характеристика & \multicolumn{4}{|c|}{$\begin{array}{l}\text { Фактические показатели } \\
\text { по мере встречаемости }\end{array}$} \\
\hline $\begin{array}{l}\text { Наличие места под на- } \\
\text { саждения по сторонам } \\
\text { света, от } 1 \text { до } 4\end{array}$ & 4 & 2 & 3 & 1 \\
\hline $\begin{array}{l}\text { Наличие деревьев и ку- } \\
\text { старников по сторонам } \\
\text { света, от } 1 \text { до } 4\end{array}$ & 1 & 2 & 3 & 4 \\
\hline $\begin{array}{l}\text { Нормы размещения } \\
\text { 1,5 м до кустарника }\end{array}$ & $\star 1)$ & - & + & \\
\hline 5,0 м до дерева & * & - & + & \\
\hline
\end{tabular}

Озелененные территории специального назначения. Объекты озеленения этой категории должны выполнять важнейшую функцию насаждений - обеспечение санитарно-эпидемиологических и экологических норм, ограждая объекты, которые являются источником воздействия на окружающую среду, и объекты, которые необходимо охранять от влияния городской среды. В этой категории можно выделить до 14 типов объектов. Основные - это санитарно-защитные зоны предприятий, ЛЭП, трубопроводов, кладбищ, портов, аэропортов, санитарные разрывы дорог, водоохранные зоны, особо охраняемые природные территории, курорты и др. В статье рассмотрены четыре типа.

Водоохранной зоной является территория, примыкающая к береговой линии рек и других водных объектов, где устанавливается специальный режим деятельности в целях предотвращения загрязнения, засорения, заиления, истощения водных объектов и сохранения среды обитания живых организмов. Согласно ст. 65 гл. 6 Водного кодекса Российской Федерации от 3 июня 2006 г. № 74-Ф3, ширина водоохранной зоны устанавливается от истока для рек или ручьев протяженностью до 10 км - в размере 50 м; от 10 до 50 км - в размере 100 м; от 50 км и более в размере 200 М. В пределах водоохранных зон организуются прибрежные защитные полосы, на территориях которых вводятся дополнительные ограничения природопользования, шириной от 15 до 100 м в зависимости от уклона и характера прилегающих земель. Водоохранные зоны водотоков подвержены интенсивному антропогенному воздействию, обычно неконтролируемой рекреации и связанным с нею замусориванию и захламлению не только прибрежных защитных полос, но и самих водных объектов. Отмечается сброс неочищенных, 
в том числе ливневых вод и теоретически очищенных канализационных стоков. Наличие и правильная структура водоохранной зоны поддерживают водные объекты в состоянии, которое отвечает экологическим требованиям. Водоохранные зоны могут в полной мере соответствовать своему назначению лишь при выполнении ряда требований, прежде всего касающихся наличия высокой доли озеленения участков в границах водоохранных зон [1; 10]. Насаждения на этих участках защищают водоемы и водотоки от запыления, действия ветров, поступления в них воды с водосбора и смыва с территории, уменьшают потери воды при испарении.

В связи с тем что во всех поселениях ширина и содержание водоохранных зон преимущественно не соблюдаются, кроме выполнения в отдельных случаях требования о размещении на их территориях инорормационных щитов, обследовались прибрежные защитные полосы шириной в среднем около 20 м. При полевом сборе материала осуществлялся прямой переход в границах прибрежной защитной полосы по каждому берегу реки в пределах города. Фиксировались данные по четырем компонентам структуры - застроенные участки, обычно частными домами, дорогами, а также заасфальтированными, замощенными набережными; покрытые растительностью, обычно древесной и кустарниковой, а также заболоченные; оголенные и недоступные для прохождения, обычно огороженные практически до уреза воды. Анализ совокупных данных по восьми рекам (по две в каждом городе, общая длина обследованной территории составляет 293 км) показывает, что 36 \% (более 107 км) прибрежной полосы оголено, и это не только естественные песчаные или галечные пляжи, но и огромные участки, вытоптанные и заезженные автомобилями, т. е. покрытые стихийной тропиночно-дорожной сетью. Растительностью занято всего 32 \% территории, но не более $25 \%$ от этого - полноценными деревьями и кустарниками. Искусственными материалами - асфральтом, бетоном и постройками - покрыто 23 \%, 9 \% (около 24 км) недоступно - огорожено, в основном это участки частного сектора, но много и промышленных предприятий, расположенных в водоохранной зоне. Компонентная структура по обоим берегам всех анализируемых рек представлена на рисунке. Крупные объекты озеленения часто располагаются в границах водоохранных зон. В исследованных городах такие есть только в Иркутске, например бульвар Гагарина на реке Ангаре. Река Туул на территории Улан-Батора отличается очень широкой речной долиной - до 1 км и более, практически свободной даже в границах города. Правый берег реки Туул, которая течет по южной окраине города, ограничен укрепленной «набережной» длиной около 5 км, при этом левый берег на всем протяжении свободен, и дома располагаются на удалении от русла. Конечно, на этих территориях насаждений, особенно древесных, почти нет, но есть кустарник. Река Дунд-Гол течет через густо населенные районы, и на десятки километров, даже за границами Улан-Батора, прямо по берегам, близко к урезу воды, располагаются юрты.

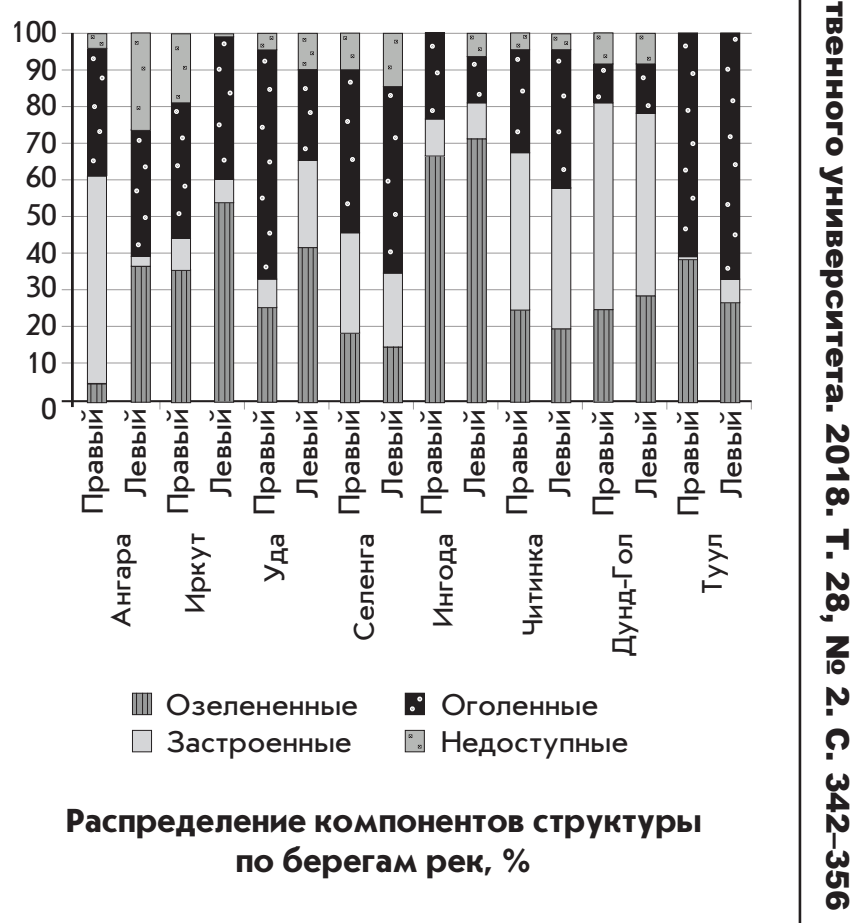

На каждом водотоке отмечено несанкционированное складирование мусора по берегам, в том числе в прибрежной полосе; сброс загрязненных ливневых вод; самозахват земель прибрежной защитной полосы; ограничение свободного доступа к воде; незаконное строительство - дома частного сектора, торговые центры, предприятия и автомобильные стоянки. Статистика Федеральной службы по надзору в сорере природопользования обозначает следующую тенденцию: чаще всего нарушения в сорере экологии совершают юридические (около $46 \%$ всех нарушений) и должностные лица (около $44 \%$ всех нарушений) [11].

Полное отсутствие древесных и кустарниковых насаждений на прибрежных защитных полосах и их замощение приводят к неконтролируемому смыву мусора, нефтепродуктов, химикатов, противогололедных смесей, фекалий, другой отмершей органики и неорганических веществ с окружающей территории.

Санитарно-защитная зона (СЗ3) - это территория, отделяющая здания и сооружения 
с технологическими процессами, относящиеся к предприятию, являющемуся источником воздействия на среду обитания и здоровье человека, от жилой застройки. Такие зоны выполняют функции фильтрации, экранирования, ассимиляции загрязнителей атмосферного воздуха, снижая негативное воздействие до уровня, соответствующего санитарно-эпидемиологическим требованиям и гигиеническим нормативам. Территория СЗ3 также предназначена для организации дополнительных озелененных площадей. В России в соответствии с санитарной классификацией предприятий, производств и объектов (по СанПиН 2.2.1/2.1.1.1200-03 «Санитарно-защитные зоны и санитарная классификация предприятий, сооружений и иных объектов») устанавливаются следующие размеры С33: для предприятий I класса 1000 м; II класса - 500 м; III класса - 300 м; IV класса - 100 м; $\vee$ класса - 50 м [3]. С3З для предприятий IV , V классов должна быть озеле- нена не менее чем на 60 \%; для предприятий II и III класса — не менее чем на 50 \%. Для предприятий, имеющих СЗ3 1000 м и более, озеленено должно быть не менее 40 \% ее территории с обязательной организацией полосы древесных и кустарниковых насаждений со стороны жилой застройки [12].

Класс опасности предприятия точно установить практически невозможно (информация закрыта), для статьи он определялся по указанным СанПиН 2.2.1/2.1.1.1200-03, где учитывается вид производимой продукции. Для аэропортов ширина СЗ3 рассчитывается в каждом конкретном случае, однако в связи с тем, что официальные данные труднодоступны, исследована минимальная СЗ3 в 50 м. ТЭЦ (ТЭС) могут иметь СЗЗ от 300 до 1000 м в зависимости от мощности и используемого топлива. В этом типе озелененных территорий обследовано всего 35 объектов - наиболее крупные предприятия (табл. 8).

Таблица 8

Характеристика некоторых санитарно-защитных зон предприятий

\begin{tabular}{|c|c|c|c|c|}
\hline \multirow[b]{2}{*}{ Объект озеленения } & \multirow[b]{2}{*}{$\begin{array}{l}\text { Размер } \\
\text { С } 33, M^{1)}\end{array}$} & \multicolumn{2}{|r|}{ В границах С33 } & \multirow[b]{2}{*}{$\begin{array}{l}\text { Защитная } \\
\text { полоса, \% }\end{array}$} \\
\hline & & $\begin{array}{l}\text { Озелене- } \\
\text { ние, \% }\end{array}$ & Запрещенные к размещению объекты & \\
\hline Аэропорт (И) & 50 & 5 & Жилье дома & - \\
\hline Аэропорт (УБ) & 50 & 0 & Жилые дома & - \\
\hline Аэропорт (УУ) & 50 & 5 & Дачи, река & - \\
\hline Аэропорт (Ч) & 50 & 1 & Дома, дачи & - \\
\hline ТЭЦ-2 (И) & 500 & & $\begin{array}{c}\text { Дома, дачи, образовательные } \\
\text { учреждения }\end{array}$ & - \\
\hline ТЭЦ-3 (УБ) & 300 & 0 & $\begin{array}{l}\text { До домов менее } 50 \text { м, до больницы } \\
230 \text { м }\end{array}$ & - \\
\hline ТЭЦ-4 (УБ) & 300 & 0 & $\begin{array}{c}\text { До домов на севере, юге и западе } \\
50-100 \text { м }\end{array}$ & - \\
\hline ТЭЦ-1 (УУ) & 300 & 0 & До садоводства менее 200 м & - \\
\hline ТЭЦ-1 (Ч) & 300 & 0 & Водоохранная зона & - \\
\hline Молокозавод (И) & 50 & 5 & Дома, техникум & 10 \\
\hline Авиазавод (И) & 500 & 15 & Жилые дома, больница & 20 \\
\hline Промзона в Кхору 20 (УБ) & 50 & 0 & Дома, юрты, магазины & - \\
\hline $\begin{array}{l}\text { Производство бетона и кирпича } \\
\text { в Кхору } 11 \text { (УБ) }\end{array}$ & 50 & 0 & До домов 25 м & - \\
\hline $\begin{array}{l}\text { Завод по производству } \\
\text { троллейбусов (УБ) }\end{array}$ & 50 & 0 & До домов менее 20 м & - \\
\hline Фабрика кашемира (УБ) & 50 & 0 & Дома у забора, 15 м & - \\
\hline $\begin{array}{l}\text { Приборостроительное } \\
\text { объединение (УУ) }\end{array}$ & 100 & 0 & До домов, лицея менее 30 м & 5 \\
\hline Авиазавод (УУ) & 300 & 0 & По забору - дома частного сектора & - \\
\hline Хлебозавод № 1(УУ) & 50 & 0 & Дома, больница & 0 \\
\hline $\begin{array}{l}\text { Промзона по проспекту } \\
\text { Строителей (УУ) }\end{array}$ & 50 & 0 & Жилые кварталы, школы & 0 \\
\hline Станкостроительный завод (Ч) & 100 & 0 & $\begin{array}{c}\text { Дома, школа, территория зарастает } \\
\text { на } 30 \%\end{array}$ & 50 \\
\hline Хлебозавод № 2 (Ч) & 50 & 0 & Частный сектор, детский сад & 0 \\
\hline Карат (Ч) & 100 & 0 & Детский сад, дома & 0 \\
\hline
\end{tabular}

1) Пояснения по определению размера даны в тексте статьи. 
Ни одно из предприятий не соблюдает регламент СЗ3. Озеленение чаще всего имеется лишь на небольших ее участках. На 27 объектах насаждения единичны или отсутствуют полностью. На 15 отмечены насаждения, но они относятся к озеленению домов, школ и больниц, расположенных в границах СЗ3. У всех предприятий отсутствуют защитные полосы насаждений со стороны селитебной застройки. Катастрофическое состояние имеющегося абсолютно неухоженного скудного озеленения не позволяет ему обеспечивать выполнение своих экологических и медико-социальных функций, что не может не сказываться на состоянии атмосферного воздуха в столицах регионов Байкальской природной территории. На практике требования, регламентирующие содержание C33, не соблюдаются, и на их территории размещаются жилые здания, образовательные и лечебные учреждения. Значимым является тот фракт, что место для размещения защитных полос фактически есть всегда, но занято оно бесчисленными проездами, вытоптанными пустырями, несанкционированными стоянками автотранспорта, свалками строительного и бытового мусора.

Помимо перечисленных, наиболее крупных предприятий, во всех городах размещается множество котельных, заправок, бетонных заводов, лесопильных мастерских, мастерских по обработке камня и мрамора, мест с контейнерами для сбора мусора, которые также должны иметь озелененные санитарные разрывы, но их состояние примерно одинаково с СЗ3 предприятий.

Автомобильные дороги как элемент населенного пункта такой же распространенный компонент, как и дома. Их структура в горизонтальном сечении сложна и содержит больше десяти элементов - от самого дорожного полотна (проезжая часть, знаки, бордюры, тротуары, ограждения) до озелененной территории и насаждений. Автомобильные дороги в соответствии с фредеральным законом «Об автомобильных дорогах и о дорожной деятельности в Российской Федерации» от 8 ноября 2007 г. № 257 по ряду признаков делятся на несколько категорий - по принадлежности (федеральные, местные и др.), по условиям движения (скоростные, обычные и др.), по транспортно-эксплуатационным характеристикам и потребительским свойствам в зависимости от ширины и количества полос движения, по интенсивности движения и др. От места в такой сложной классификации зависит структура автомобильной дороги и размещение насаждений в ее границах. Наиболее верной является как минимум трехполосная посадка дерево - кустарник - дерево. Остатки такой формы озеленения разной длины отмечены вдоль дорог во всех городах (ул. Лермонтова в Иркутске, ул. Мира в Улан-Баторе и др.), но полноценного и тем более по всей длине улицы озеленения нигде не осталось. Преимущественно утрачены кустарники и живые изгороди.

Озеленение автомобильных дорог выполняет целый комплекс экологических и санитарно-эпидемиологических фрункций: уменьшает шум, загазованность, запыление, выполняет почво- и водоохранные функции, улучшает видеоэкологические характеристики, направляет водителя и обеспечивает защиту проезжей части дороги от снежных заносов и ветра. Насаждения в границах отвода автомобильных дорог относятся к насаждениям широкого использования, поскольку жители городов проводят на улицах значительное время [13; 14]. Следовательно, создание на улицах оптимальных условий всесторонней безопасности - важная задача.

Обследовано 65 объектов, представлена информация об основных, главных улицах (табл. 9). Ни одной автомобильной дороги, озелененной по регламенту (около 50 \% обеспеченности насаждениями), нет. В последнее время в России появились ограждения дорог, уменьшающие наезды автотранспорта на обочины, что, возможно, приведет к восстановлению травянистого покрова и улучшению показателей почвы, но без рыхления и отсыпки почвосмесями этот процесс может занять годы. Реконструкции улиц приводят только к снижению доли озеленения, несмотря на осуществляющуюся допосадку. Вдоль автомагистралей наблюдается преждевременное ослабление, частичное усыхание и старение деревьев и кустарников.

Таблица 9

Характеристика некоторых автомобильных дорог

\begin{tabular}{|l|c|c|c|c|}
\hline \multicolumn{1}{|c|}{ Объект озеленения } & Длина, М & $\begin{array}{c}\text { Длина (с двух сторон) } \\
\text { Участков С ДКР, М/\% }\end{array}$ & $\begin{array}{c}\text { Наличие объектов } \\
\text { озеленения }\end{array}$ & $\begin{array}{c}\text { Количество полос } \\
\text { движения }\end{array}$ \\
\hline Улица Ленина (И) & 742 & $102 / 7$ & $5(11)^{1)}$ & $4-8$ \\
\hline Улица Ленина (УУ) & 1560 & $1175 / 38$ & $1(2)$ & $2-4$ \\
\hline Улица Ленина (Ч) & 4900 & $4104 / 42$ & 2 & 4 \\
\hline Улица Мира (УБ) & 12200 & $6892 / 28$ & $4(7)$ & $4-6$ \\
\hline
\end{tabular}

1) В скобках указано число объектов, соответствующих лишь условно: либо деревья единичны, либо ограничено посещение и др. 
Проблема неисполнения регламентирующих документов по содержанию насаждений вдоль дорожного полотна населенных пунктов имеет несколько причин: недостаток места для размещения насаждений (бо́льшая часть дорог города даже не в красных линиях не соответствует санитарно-гигиеническим требованиям по ширине), низкая выживаемость древесных пород в городах и невыполнение нормативов дорожного строительства. Именно насаждения должны образовывать новые элементы ландшафта городов и улучшать существующие, гармонично сочетая дорогу с окружающей местностью.

Жилую застройку, согласно СП 42.13330.2016 «Градостроительство. Планировка и застройка городских и сельских поселений», необходимо отделять от железных дорог санитарным разрывом шириной 100 м, считая от оси крайнего железнодорожного пути. Допустимо уменьшение ширины, но не более чем на 50 м. Не менее 50 \% площади разрыва должно быть озеленено. В границах всех рассматриваемых в статье городов проходят участки железных дорог: около 30 км - по Иркутску, более 55 км - по Улан-Удэ, около 40 км - по Чите и сеть - более 70 км - по Улан-Батору. Фактически санитарные разрывы на основной части дорог не соблюдаются, и жилые дома, офисные здания, учреждения образования и здравоохранения располагаются в зоне влияния железнодорожного транспорта. Соответственно, все живущие и работающие в этой полосе подвергаются шумовому воздействию около 90 децибел и влиянию целого ряда отравляющих веществ, например креозота. Но даже при наличии некоторого расстояния насаждения, особенно древесные и кустарниковые, на этих территориях отсутствуют.

Заключение. Выявленные сходные проблемы озеленения столиц регионов, входящих в состав Байкальской природной территории, обусловлены общими тенденциями мировой урбанизации. На момент обследования из 1118 объектов озеленения лишь $13 \%$ условно соответствовали регламенту структуры и состояния. Еще около 20 \% объектов отмечались как почти соответствующие, т. е. насаждения и структура озелененной территории имели 50 \% соответствия нормам. Около 40 \% обследованных объектов вообще не имели насаждений, на остальных $27 \%$ посадки отмечены скорее единично. Из проанализированных населенных пунктов полнее всего озеленен Иркутск, затем Чита, Улан-Удэ и Улан-Батор. В качестве основных проблем, не останавливаясь на ошибках российского законодательства, не отражающего современные мировые векторы развития поселений, можно указать следующие:

- тотальный недостаток доли насаждений при наличии мест, участков под их размещение и стабильное уменьшение площадей уже озелененных территорий категории общего пользования. Низкий показатель сомкнутости крон, в том числе в результате неправильной подрезки. На многих типах озелененных территорий доля насаждений является превалирующим критерием для выполнения ими санитарных и других функций;

- отсутствие обоснованного планирования восстановления, развитияи замены насаждений, а также целевого назначения объектов, что становится предпосылкой появления всех имеющихся проблем;

- ошибки в агротехнике, в том числе катастрофические для насаждений, часто отсутствие элементарного ухода, что в основном приводит к ухудшению их состояния;

- использование озелененных территорий под стоянки, размещение мусора и снега, стихийное формирование тропиночно-дорожной сети, что может привести к тотальной гибели, болезни насаждений в городах.

Решение проблем видим в следующем:

1. Не просто создание концептуальной стратегии озеленения, формирующего благоприятную окружающую среду, а критериальное датированное планирование, основанное на значимых показателях устойчивого безопасного развития поселений.

2. Использование научно обоснованной, адаптированной методики оценки состояния озелененных территорий, имеющей отличительные особенности в зависимости от их категории, типа, а также страны, региона и географической зоны.

3. Актуальная инвентаризация насаждений и паспортизация всех объектов озеленения с учетом типовых профильных характеристик.

4. Своевременная доработка и корректировка законодательства с учетом наилучших существующих методов и приемов озеленения.

5. Использование полноценной мониторинговой программы, разработка ее плана и назначение ответственных за ее контролирование.

С сожалением приходится констатировать, что в фредеральной целевой программе «Охрана озера Байкал и социально-экономическое развитие Байкальской природной территории на 2012-2020 годы» нет ни од- 
ного целевого показателя, непосредственно направленного на улучшение состояния поселений, и особенно городов, за исключением, возможно, такого показателя, как «снижение общей площади территории Байкальской природной территории, подвергшейся высокому и экстремально высокому загрязнению». До завершения программы осталось менее двух лет. Улучшение значений индикаторов в отчетах о реализации программы не подтверждается реальным улучшением экологии городов Байкальского региона.

Полиморфизм в особенностях рассмотренных в статье городов, отражающий исторические, религиозные, культурные, этнические и эстетические ценности, должен уважаться, поощряться и сохраняться. Благодаря программам ООН по содействию устойчивому развитию населенных пунктов - Хабитат и профилированию жизнеспособности городов появились некоторые единые тре- бования, предъявляемые к качеству среды обитания человека, определены показатели контроля состояния, выделены критерии, которые возможно использовать в качестве базовых индикаторов устойчивого развития. Программы зеленого экологического строительства способствуют увеличению площади озеленения населенных пунктов благодаря использованию разнообразных методов. Именно озеленение территорий считается достаточно дешевым, но при этом высокоэффрективным способом очистки воздуха, вод, почв, регулирования большинства физических и химических показателей сред. Все эти механизмы изменения среды обитания человека, способствующие созданию умного экологичного города, получают все более широкое распространение. Наша задача как ученых и как жителей уникальной природной территории - сделать ее модельной по изменению эффрективности хозяйствования.

\section{СПИСОК ИСПОЛЬЗОВАННОЙ ЛИТЕРАТУРЫ}

1. Водоохранное зонирование байкальской природной территории: правовые коллизии, ландшафтно-гидрологический подход / И. В. Бычков [и др.] / / География и природные ресурсы. — 2017. — № 4. - С. 76-82.

2. Tulokhonov A. K. Directions, conditions, and risks of implementation of the transport mega-projects «NorthSouth» and «East-West» under the new geopolitical realities / A. K. Tulokhonov // Geography, Environment, Sustainability. - 2017. - Vol. 10, № 1. - P. 70-77.

3. Блинов Л. Н. Большой город. Экология, безопасность жизнедеятельности / Л. Н. Блинов, В. В. Букреев, В. П. Ложечко. - СПб. : Изд-во Политех. ун-та им. Петра Великого, 2014. - 405 с.

4. Zaremba M. Satellite guided navigation control for environment monitoring / M. Zaremba, F. Halal, P. Pedrocca, T. Hirose / / Annual Review of Earth and Planetary Sciences. — 2015. — № 24. - P. 129-144.

5. Потапова Е. В. Состояние озелененных территорий категории общего пользования г. Рязани / Е. В. Потапова, Е.В.Зелинская // Вестник Тверского государственного университета. Сер.: Биология и экология. 2016. - № 1. - C. 142-149.

6. Экологические классификации видов растений / Б. М. Миркин [и др.] // Журнал общей биологии. 2018. - T. 79, № 1. - С. 64-75.

7. Ливио М. Был ли Бог математиком? / Марио Ливио ; пер. А. Бродоцкой. - М. : АСТ, 2016. - 383 с.

8. Gottfried D. Greed to Green / D. Gottfried. - Berkeley, CA: World Build Publishing, 2004. - 243 p.

9. Ranganathan S. R. Energy in Buildings [Electronic resource] / S. R. Ranganathan. - Mode of access: www. eesi.org/publications/Fact\%20Sheets/Buildings_energy_9.11.06.PDF.

10. Regional geographic information systems of health and environmental monitoring / S. A. Kurolap [et al.] // Baltic Region. - 2016. - Vol. 8, № 4. - P. 108-124.

11. Якимова Е. М. Международное сотрудничество в борьбе с экологическими преступлениями / Е. М. Якимова, В. В. Чуксина, Г. Н. Комкова, С. Э. Несмеянова // Всероссийский криминологический журнал. - 2018. - T. 12, № 2. - C. 288-298. - DOI: 10.17150/2500-4255.2018.12(2).288-298.

12. Битюкова В. Р. Изменение антропогенного воздействия производственных зон Москвы за последние десятилетия / В. Р. Битюкова, Т. Д. Саульская // Вестник Московского университета. Сер. 5, География. 2017. - № 3. - С. 24-33.

13. Воронова Т. С. Экологические особенности условий жизни населения Москвы в конце XIX - начале XX века / Т. С. Воронова // Вестник Московского городского педагогического университета. Сер.: Естественные науки. - 2017. - № 2 (26). - С. 70-76.

14. Vologzhina S. Zoning of the territory of Irkutsk (Russia) based on integrated assessment of air pollution / S. Vologzhina, E. Sutyrina, A. Akhtimankina // $14^{\text {th }}$ International multidisciplinary scientific geoconference and EXPO SGEM, Albena, 19-25 June, 2014. - Albena, 2014. - B. 4, vol. 2. - P. 615-622.

\section{REFERENCES}

1. Bychkov I. V. ,Gagarinova O. V., Orlova I. I., Korytnyi L. M., Plyusnin V. M., Bogdanov V. N. Water protection zoning of the baikal natural territory: conflicts of laws, landscape-hydrological approach. Geografiya I prirodnye resursy $=$ Geography and natural resources, 2017, no. 4, pp. 76-82. (In Russian).

2. Tulokhonov A. K. Directions, Conditions, and Risks of Implementation of the Transport Mega-Projects «NorthSouth» and «East-West» under the New Geopolitical Realities. Geography, Environment, Sustainability (GES Journal), 2017, vol. 10, no. 1, pp. 70-77. 
3. Blinov L. N., Bukreev V. V., Lozhechko V. P. Bolshoi gorod. Ekologiya, bezopasnost zhiznedeyatelnosti [A Big City. Ecology, Health and Safety]. Peter the Great St. Petersburg Polytechnic University Publ., 2014. 405 p.

4. Zaremba M., Halal F., Pedrocca P., Hirose T. Satellite guided navigation control for environment monitoring. Annual Review of Earth and Planetary Sciences, 2015, no. 24, pp. 129-144.

5. Potapova E. V., Zelinskaya E. V. Green areas of the communal use in the city of Ryazan (Russia): problems and perspectives. Vestnik Tverskogo Gosudarstvennogo Universiteta. Seriya: Biologiya $i$ ekologiya $=$ Herald of TVGU. Series: Biology and Ecology, 2016, no. 1, pp. 142-149. (In Russian).

6. Mirkin B. M., Naumova L. G., Golub V. B., Khaziakhmetov R. M. Ecological classifications of plant species. Zhurnal obshchei biologii = General Biology Journal, 2018, vol. 79, no 1, pp. 64-75. (In Russian).

7. Livio Mario. Is God a Mathematician? New York, Simon \& Schuster, 2009. 320 p. (Russ. ed.: Livio Mario. Byl li bog matematikom? Moscow, AST Publ., 2016. 383 p.).

8. Gottfried D. Greed to Green. Berkeley, CA, World Build Publishing, 2004. 243 p.

9. Ranganathan S. R. Energy in Buildings. Available at: www.eesi.org/publications/Fact\%20Sheets/Buildings_ energy_9.11.06.PDF.

10. Kurolap S. A., Klepikov O. V., Vinogradov P. M., Gritsenko V. A. Regional geographic information systems of health and environmental monitoring. Baltic Region, 2016, vol. 8, no. 4, pp. 108-124.

11. Yakimova E. M., Chuksina V. V., Komkova G. N., Nesmeyanova S. E. International Cooperation in Counteracting Environmental Crimes. Vserossiiskii kriminologicheskii zhurnal=Russian Journal of Criminology, 2018, vol. 12, no. 2, pp. 288-298. DOI: 10.17150/2500-4255.2018.12(2).288-298. (In Russian).

12. Bityukova V. R., Saulskaya T. D. Changes of the anthropogenic impact of Moscow industrial zones during the recent decades. Vestnik Moskovskogo universiteta. Seriya 5, Geografiya = Moscow University Bulletin. Series 5, Geography, 2017, no. 3, pp. 24-33. (In Russian).

13. Voronova T. S. Ecological Features of the Living Conditions of the Population of Moscow in the Late XIX Early XX Century. Vestnik Moskovskogo gorodskogo pedagogicheskogo universiteta. Seriya: Estestvennye nauki $=$ Moscow city university. Series Natural Sciences, 2017, no. 2 (26), pp. 70-76. (In Russian).

14. Vologzhina S., Sutyrina E., Akhtimankina A. Zoning of the territory of Irkutsk (Russia) based on integrated assessment of air pollution. $14^{\text {th }}$ International multidisciplinary scientific geoconference and EXPO SGEM, Albena, 19-25 June, 2014. Albena, 2014, b. 4, vol. 2, pp. 615-622.

\section{Информация об авторах}

Суходолов Александр Петрович - доктор экономических наук, профессор, заслуженный экономист Российской Федерации, ректор, Байкальский государственный университет, 664003, г. Иркутск, ул. Ленина, 11, e-mail: rector@bgu.ru.

Потапова Елена Владимировна - доктор сельскохозяйственных наук, кандидат биологических наук, доцент, кафедра гидрологии и природопользования, Иркутский государственный университет, 664033, г. Иркутск, ул. Лермонтова, 126, e-mail: e.v.potapova.isu@mail.ru.

Изместьев Александр Анатольевич - кандидат экономических наук, доцент, кафедра экономики и управления бизнесом, ученый секретарь университета, Байкальский государственный университет, 664003, г. Иркутск, ул. Ленина, 11, e-mail: IzmestevAA@bgu.ru.

Гусева Инесса Константиновна - доцент, кафедра экономики и управления бизнесом, председатель профкома, Байкальский государственный университет, 664003, г. Иркутск, ул. Ленина, 11, e-mail: GusevalK@bgu.ru.

\section{Для цитирования}

Суходолов А. П. Озеленение крупных городов Байкальского региона - Иркутска, Улан-Удэ, Читы и Улан-Батора / А. П. Суходолов, Е.В.Потапова, А. А. Изместьев, И. К. Гусева / / Известия Байкальского государственного университета. - 2018. T. 28, № 2. - C. 342-356. - DOI: $10.17150 / 2500-$ 2759.2018.28(2).342-356.

\section{Authors}

Alexander P. Sukhodolov - D.Sc. in Economics, Professor, meritorious economist of the Russian Federation, Rector of Baikal State University, 11 Lenin St., 664003, Irkutsk, the Russian Federation, e-mail: rector@bgu.ru.

Elena V. Potapova - D.Sc. in Agricultural Science, Ph.D. in Biology, Associate Professor, Department of Hydrology and Environmental Management, Irkutsk State University, 126 Lermontov St., 664033, Irkutsk, the Russian Federation, e-mail: e.v.potapova.isu@ mail.ru.

Alexander A. Izmestiev - Ph.D. in Economics, Associate Professor, Department of Economics and Business Management, academic secretary of University, Baikal State University, 11 Lenin St., 664003, Irkutsk, the Russian Federation, e-mail: IzmestevAA@bgu.ru.

Inessa K. Guseva - Associate Professor, Department of Economics and Business Management, President of the Trade Union, Baikal State University, 11 Lenin St., 664003, Irkutsk, the Russian Federation, e-mail: GusevalK@bgu.ru

\section{For citation}

Sukhodolov A. P., Potapova E. V., Izmestiev A. A., Guseva I. K. Planting of Greenery in Large Cities of the Baikal Region: Irkutsk, Ulan-Ude, Chita and Ulaanbaatar. Izvestiya Baykal' skogo gosudarstvennogo universiteta $=$ Bulletin of Baikal State University, 2018, vol. 28 , no. 2 , pp. 342-356. DOI: $10.17150 / 2500-$ 2759.2018.28(2).342-356. (In Russian).

Переводчик: А. П. Бреева, Е. А. Универсалюк. Верстка: А. С. Ларионова.

Подписано в печать 21.05.18. Дата выхода 14.06.18. Формат 62х84 1/8. Тираж 1000 экз. Усл. печ. л. 22,6. Цена 700 р. Заказ 6648 